\title{
Correction to: Reduced-form mechanism design and ex post fairness constraints
}

\section{Erya Yang ${ }^{1}$}

Published online: 12 November 2021

(c) The Author(s) 2021

\section{Correction to: Economic Theory Bulletin https://doi.org/10.1007/s40505-021-00211-1}

We regret that during proof correction stage, the following errors were inadvertently made by our production team:

In the Abstract, the citation "Border in Economet J Econ Soc, 59(4):1175-1187, 1991" should be "Border in Econometrica 59(4):1175-1187, 1991"

The journal name mentioned in the reference "Border (1991)" was also incorrect. It should read as given below:

Border, K.C.: Implementation of reduced form auctions: a geometric approach. Econometrica 59(4), 1175-1187 (1991)

In the Abstract, the citation "Gutmann et al. (Ann Prob 19:1781-1797, 1991)" should be "Gutmann et al. (Ann Prob 19(4):1781-1797, 1991)".

In footnote 2, "(see Vohra 2011) in particular, the discussion in sect. 6.2" should be "(see Vohra 2011, in particular, the discussion in Sect. 6.2)."

In Eq. 4.1, parentheses are missing when referring to equation 3.4a. It should be (3.4a). In the Proof of lemma 4.4, parentheses are missing when referring to equations. So, $4.4 \mathrm{~b}, 4.3,4.4 \mathrm{c}, 4.4 \mathrm{~b}, 4.3,4.4 \mathrm{c}$ should be $(4.4 \mathrm{~b}),(4,3),(4,4 \mathrm{c}),(4,4 \mathrm{~b}),(4.3),(4,4 \mathrm{c})$.

The publisher for the reference "Benedetto and Czaja (2010)" was incorrect. It should be Birkhauser Boston.

The publisher for the reference "Borgers and Krahmer (2007)" was incorrect. It should be Oxford University Press, USA, New York.

The original article can be found online at https://doi.org/10.1007/s40505-021-00211-1.

\footnotetext{
$凶 \quad$ Erya Yang

eryay@uci.edu

1 Department of Economics, University of California, Irvine, CA, USA
} 
The Publisher for the reference "Vohra (2011)" was incorrect. It should be Cambridge University Press, USA, New York.

The details of the reference "Pai and Vohra (2012)" was incorrect. The correct reference should read as given below:

Pai, M.M., Vohra, R.: Auction design with fairness concerns. Subsidies vs. setasides. Northwestern University Discussion Papers 1548 (2012).

The DOI in the reference "Wu, C., Zhong, S., Chen, G. (2014)" was incorrect. The correct DOI should be https://doi.org/10.1109/CCNC.2014.6994416.

The original article has been corrected.

Open Access This article is licensed under a Creative Commons Attribution 4.0 International License, which permits use, sharing, adaptation, distribution and reproduction in any medium or format, as long as you give appropriate credit to the original author(s) and the source, provide a link to the Creative Commons licence, and indicate if changes were made. The images or other third party material in this article are included in the article's Creative Commons licence, unless indicated otherwise in a credit line to the material. If material is not included in the article's Creative Commons licence and your intended use is not permitted by statutory regulation or exceeds the permitted use, you will need to obtain permission directly from the copyright holder. To view a copy of this licence, visit http://creativecommons.org/licenses/by/4.0/.

Publisher's Note Springer Nature remains neutral with regard to jurisdictional claims in published maps and institutional affiliations. 